\title{
PENERAPAN VARIASI MODIFIKASI BOLA KARET UNTUK MENINGKATKAN KETERAMPILAN SERVIS BAWAH SEPAK TAKRAW
}

\author{
Homarul Ashabi Saputra \\ PENJAS FKIP UNIB, e-mail: homarulashabi@gmail.com \\ Yarmani \\ Universitas Bengkulu \\ Tono Sugihartono \\ Universitas Bengkulu \\ Defliyanto \\ Universitas Bengkulu
}

\begin{abstract}
Abstrak
Penelitian ini bertujuan untuk mengetahui penerapan variasi modifikasi bola karet untuk meningkatkan keterampilan servis bawah sepak takraw. Jenis penelitian ini adalah Penelitian Tindakan Kelas dengan jumlah subjek adalah 35 orang siswa. Hasil penelitian ini menyimpulkan (1) Penerapan variasi modifikasi bola karet dalam pembelajaran PJOK dapat meningkatkan keterampilan siswa kelas X MA AL-Kariim Kabupaten Bengkulu Tengah dalam melakukan servis bawah sepak takraw. Pada Pra siklus menunjukkan nilai rata-rata yang diperoleh yaitu 45,4 dengan persentase ketuntasan 28,5\% dan jumlah siswa tuntas 10 . Selanjutnya pada siklus 1 nilai rata-rata yang diperoleh yaitu 61,4 dengan persentase ketuntasan $60 \%$ dan jumlah siswa yang tuntas 21 . Kemudian pada siklus 2 nilai rata-rata yang diperoleh yaitu 78 dengan persentase ketuntasan $85,7 \%$ dan jumlah siswa yang tuntas 30. (2) Penerapan variasi modifikasi bola karet dalam pembelajaran PJOK dapat meningkatkan aktivitas guru dan siswa dalam proses pembelajaran di kelas X MA AL-Kariim Kabupaten Bengkulu Tengah.
\end{abstract}

Kata Kunci: Sepak Takraw, Variasi Modifikasi Bola, Servis Bawah

\begin{abstract}
The ards of this research to know the application of modification rubber variations to improve service skills under sepak takraw. This research is class action research with 35 students. The result of the data analyst show that (1) By using the modification of rubber ball is a good way to improve the students skill at MA AL-Kariim Kabupaten Bengkulu Tengah in doing down service. In pra sircle
\end{abstract}


was showing the rate score were achieved 45,4 with the percentage $28,5 \%$ and the number of students who pass 10. In the first syrcle the score was 61,4 with the percentage $60 \%$ and the number of students who pass 21 . In the second syrcle the rate score was 78 with the percentage $85,7 \%$ and the number students who pass 30. (2) by using the modification of rubber ball in sport activity could able to improve the teachers and students activities in learning process in MA ALKariim Kabupaten Bengkulu Tengah at grade $X$.

Keywords : Sepak Takraw, The Modification Of Rubber Ball, Down Service

\section{PENDAHULUAN}

Pendidikan jasmani merupakan mata pelajaran untuk melatih kemampuan psikomotorik yang mulai diajarkan secara formal di sekolah dasar hingga sekolah menengah atas. Menurut Giri Wiarto (2015 : 4) bahwa pendidikan jasmani adalah suatu pendidikan yang menggunakan aktifitas jasmani sebagai media dalam mengembangkan potensi peserta didik baik psikomotor, kognitif dan afektif. Sedangkan menurut Rusli Lutan (2002 : 1) pendidikan jasmani adalah proses pendidikan melalui aktivitas jasmani untuk mencapai tujuan pendidikan.

Berdasarkan pendapat para ahli tersebut, dapat disimpulkan bahwa pendidikan jasmani adalah suatu proses pendidikan melalui aktivitas jasmani yang digunakan untuk meningkatkan kebugaran jasmani, mengembangkan keterampilan motorik, pengetahuan dan perilaku hidup sehat dan aktif, sikap sportif, dan kecerdasan emosi.

Tugas utama dalam penyelenggaraan pengajaran pendidikan jasmani adalah membantu siswa untuk menjalani proses pertumbuhan, baik yang berkenaan dengan keterampilan fisik maupun dalam aspek sikap dan pengetahuannya. Rusli Lutan(2002 : 6).

Menurut Dirjen Pendidikan dasar dan Menengah dan MENPORA, (2000: 141) sepak takraw adalah suatu bentuk permainan yang dimainkan oleh 2 regu masingmasing terdiri dari 3 pemain di atas lapangan seluas lapangan bulu tangkis, menggunakan net dan bola yang terbuat dari rotan atau bahan sintetis dengan gerakan menyepak atau menggunakan seluruh anggota badan kecuali tangan.

Sepak takraw merupakan salah satu materi pilihan yang dikembangkan di lingkungan sekolah. Namun, tidak semua sekolah mengembangkan permainan sepak takraw. Untuk dapat bermain sepak takraw yang baik, siswa dituntut untuk dapat menguasai teknik dasar dengan benar. Salah satu teknik dasar dalam permainan sepak takraw adalah teknik servis bawah (sepak mula). Servis bawah merupakan keterampilan melakukan sepakan awal dalam suatu permainan sepak takraw. Teknik ini 
merupakan teknik yang penting dalam permainan sepak takraw sehingga diharapkan siswa akan mampu menguasai teknik servis bawah dengan baik dan tepat agar siswa dapat bermain sepak takraw dengan baik.

Pembina harus mempunyai keterampilan dan inovasi dalam memberikan materi dalam melatih sepak takraw, hal ini dapat diwujudkan dengan salah satu cara yaitu dengan memodifikasi kondisi lingkungan pembelajaran seperti peralatan. Seorang pembina dapat mengurangi tingkat kesulitan tugas ajar dengan cara memodifikasi peralatan yang digunakan untuk melakukan skill tersebut. Misalnya berat ringannya, besar kecilnya, tinggi rendahnya, serta panjang pendeknya peralatan yang digunakan.

Memodifikasi peralatan diharapkan dapat menangani sulitnya melakukan servis bawah pada permainan sepak takraw. Beberapa modifikasi media pelatihan yang mudah dalam mengontrol atau menyepak dalam teknik servis bawah diharapkan siswa dapat menyepak dengan baik sehingga dalam melakukan servis bawah bola lebih mudah terkontrol. Oleh karena itu, dengan memodifikasi peralatan sepak takraw diharapkan dapat meningkatkan efektivitas pembelajaran.

Untuk mencapai suatu tujuan pembelajaran yang telah di kemukakan di atas, diperlukan peranan seorang guru maupun orang tua siswa, karena merupakan suatu faktor penunjang pencapaian tujuan pendidikan jasmani. Orang tua memiliki kedudukan penting untuk lebih jauh memikirkan perkembangan tingkah laku yang wajar memerlukan kecakapan kasih sayang orang tua, agar mereka dapat berfikir lebih dewasa guna menyikapi lingkungan sekitarnya. Salah satu peranan guru dalam mencapai tujuan pendidikan jasmani di sekolah adalah dalam proses pembelajaran. Guru hendaknya mampu mengolah pembelajaran dan mampu memberikan pembelajaran yang mudah di pahami siswa dalam proses pembelajaran tersebut.

Menurut Rusli Lutan (2002 : 9) ukuran keberhasilan proses pengajaran dalam pendidikan jasmani di pengaruhi oleh beberapa faktor yaitu : (1) Adanya rumusan tujuan pengajaran yang mengandung harapan tentang perubahan perilaku yang diharapkan. Tujuan itu merupakan titik awal dari keseluruhan proses. (2) Memiliki metode atau substansi pengajaran. Materi ini berisi tugastugas gerak, aktivitas jasmani yang direncanakan untuk dilaksanakan oleh siswa. Melalui pengalaman itu, diharapkan terjadi perubahan. (3) Adanya metode dan strategi yang diselaraskan dengan materi. Melalui metode dan strategi, materi di sajikan, dan siswa diantarkan untuk mengalami perubahan. (4) Adanya evaluasi yang bertujuan untuk mengetahui seberapa banyak perubahan yang terjadi pada siswa. 
Berdasarkan hasil pengamatan di kelas X MA Al Kariim Bengkulu Tengah yang telah dilakukan ditemukan permasalahan yaitu rendahnya kemampuan siswa dalam melakukan teknik dasar servis bawah sepak takraw dengantingkat keberhasilan pada tes awal servis bawah menggunakan bola takraw standarhanya mencapai 28,5\%, dengan kata lain hanya 10 dari 35 siswa yangdapat melakukannya dengan baik. Pada mata pelajaran PJOK di MA Al-Kariim kriteria ketuntasan minimal (KKM) yang harus dicapai siswa yaitu 76, berarti siswa yang berhasil melakukannya masih jauh dari kata baik dalam melakukan servis bawah sepak takraw.

Dari permasalahan yang telah diamati, hal ini disebabkan siswa kurang menyukai pembelajaran sepak takraw karena pembelajaran sepak takraw ini masih belum terlalu aktif di tingkat sekolah, khususnya di wilayah Bengkulu Tengah. Hendaknya pembelajaran sepak takraw harus di sejajarkan dengan materi pelajaran yang lain seperti sepak bola, bola voli, bulu tangkis maupun materi pelajaran yang lain agar siswa menyukai permainan ini.

Pembelajaran sepak takraw ini juga membuat siswa sangat kesulitan dalam mempelajari teknik dasar servis dalam permainan sepak takraw, dikarenakan kurangnya pengetahuan tentang permainan ini di masyarakat dan mereka hanya menemukan permainan ini di sekolah saja akibatnya siswa raguragu dalam melakukannya.
Permainan sepak takraw ini dimainkan dengan menggunakan bola rotan ataupun yang terbuat dari plastik, namun tekstur bola yang cukup keras membuat siswa takut dalam melakukan servis sepak takraw dengan alasan sakit jika menendangnya.

Dari masalah yang ada peneliti akan melakukan modifikasi terhadap bola takraw. Tujuannya agar siswa lebih berani dalam melakukan servis bawah permainan sepak takraw dan mengetahui pengaruh penggunaan modifikasi bola dalam melakukan servis bawah sepak takraw.

Berdasarkan permasalahan tersebut peneliti merencanakan perbaikan pada pembelajaran PJOK di kelas tersebut. Rencana perbaikan tersebut adalah dengan melakukan modifikasi bola karet permainan sepak takraw pada pembelajaran PJOK dengan meningkatkan teknik servis bawah pada siswa kelas X MA AL-Kariim Bengkulu Tengah.

\section{METODE}

Penelitian ini adalah jenis penelitian tindakan kelas, prosedur atau langkah-langkah yang dilakukan dalam penelitian ini dilaksanakan dalam kegiatan yang berbentuk siklus penelitian. Dalam penelitian ini menggunakan dua siklus, setiap siklusnya terdapat dua pertemuan.

Prosedur penelitian terdiri dari empat tahap yaitu perencanaan awal, pelaksanaan tindakan, observasi dan refleksi. Hal tersebut harus direncanakan secara matang 
dan sistematis untuk mendapatkan hasil yang sesuai dengan keinginan.

Subyek penelitian adalah siswa kelas $\mathrm{X}$ yang berjumlah 35 orang siswa yang terdiri dari 20 siswa putra dan 15 siswa putri. Tempat penelitian tindakan kelas ini adalah di MA Al-Kariim Pondok Kelapa Bengkulu Tengah.

Waktu pelaksanaan penelitian dilakukan pada semester 2 tahun ajaran 2016/2017.

\section{HASIL DAN PEMBAHASAN \\ Hasil}

Penelitian yang telah dilaksanakan di kelas X MA Al-Kariim Bengkulu Tengah merupakan suatu penelitian tindakan kelas (classroom action research). Penelitian tindakan yang telah dilakukan ini terdiri dari dua siklus, yang setiap siklusnya terdiri dari empat tahap yaitu perencanaan, tindakan, pengamatan, dan refleksi. Hasil penelitian yang dilakukan pada siswa kelas $\mathrm{X}$ yang berjumlah 35 melalui pembelajaran servis bawak sepak takraw yang dimodifikasi dengan bola karet terhadap keterampilan siswa pada pembelajaran PJOK, diperoleh hasil bahwa keterampilan servis bawah sepak takraw meningkat menjadi $85,7 \%$ serta aktivitas guru mencapai $93,7 \%$ dan aktivitas siswa $87,5 \%$ dapat dilihat pada siklus 2. Data awal diperoleh dari tes pra siklus yang di ikuti oleh 35 siswa kelas $X$ MA Al Kariim Kabupaten Bengkulu Tengah diperoleh tingkat keterampilan servis bawah sepak takraw adalah :

Tabel 1 Data Hasil Tes Pra Siklus

\begin{tabular}{|c|c|}
\hline Rata-Rata & $\mathbf{4 5 , 4}$ \\
\hline $\begin{array}{c}\text { Jumlah Siswa } \\
\text { Tuntas }\end{array}$ & 10 \\
\hline $\begin{array}{c}\text { Persentase } \\
\text { Ketuntasan }\end{array}$ & $\mathbf{2 8 , 5 \%}$ \\
\hline
\end{tabular}

Berdasarkan tabel 4.1 data hasil tes pra siklus tersebut, dapat dilihat bahwadari 35 siswa kelas X MA ALKariim hanya 10 siswa yang tuntas dalam melakukan servis bawah sepak takraw. Hal ini menunjukkan bahwa secara keseluruhan siswa mempunyai tingkat keterampilan servis bawah sepak takraw dengan kategori kurang dan nilai rata-rata pada pra siklus ini sebesar 45,4 dengan persentase ketuntasan $28,5 \%$ dan siswa yang belum tuntas $71,5 \%$.

Siklus Pertama

\section{A. Aktivitas Guru}

Hasil pengamatan aktivitas guru dalam pembelajaran yang dilakukan oleh satu orang pengamat selama kegiatan pembelajaran dengan menggunakan modifikasi bola karet sepak takraw dapat di lihat pada tabel berikut.

Tabel 2 Data Hasil Aktivitas

Guru pada Siklus 1

\begin{tabular}{|c|c|}
\hline ASPEK & HASIL \\
\hline Jumlah Skor & 11 \\
\hline Persentase & $68,7 \%$ \\
\hline Kriteria & Belum Tuntas \\
\hline
\end{tabular}

Berdasarkan tabel 4.2 data hasil aktivitas guru pada siklus 1 menunjukkan bahwa jumlah skor hasil pengamatan aktivitas guru adalah 11 (68,7\%), dengan demikian kriteria yang dicapai untuk aktivitas guru pada siklus 1 adalah belum tuntas. Hal ini dapat disimpulkan bahwa aktivitas guru dalam 
pembelajaran penjas dengan materi sepak takraw melalui penerapan modifikasi bola karet pada siklus 1 belum berhasil dan perlu perbaikan pada siklus berikutnya

\section{B. Aktivitas Siswa}

Hasil pengamatan aktivitas siswa dalam pembelajaran yang dilakukan oleh satu orang pengamat selama kegiatan pembelajaran dengan menggunakan modifikasi bola karet sepak takraw dapat dilihat pada tabel berikut :

Tabel 3 Data Hasil Aktivitas Siswa Pada Siklus 1

\begin{tabular}{|c|c|}
\hline ASPEK & HASIL \\
\hline Jumlah Skor & 10 \\
\hline Persentase & $62,5 \%$ \\
\hline Kriteria & Belum \\
& Tuntas \\
\hline
\end{tabular}

Berdasarkan tabel 4.3 data hasil aktivitas siswa pada siklus 1 menunjukkan bahwa jumlah skor hasil pengamatan aktivitas siswa adalah 10 (62,5\%), dengan demikian kriteria yang dicapai untuk aktivitas siswa pada siklus 1 adalah belum tuntas. Hal ini dapat disimpulkan bahwa aktivitas siswa dalam pembelajaran PJOK dengan materi sepak takraw melalui penerapan modifikasi bola karet pada siklus 1 belum berhasil dan perlu ada perbaikan pada siklus berikutnya.

C. Deskripsi Keterampilan Servis

Bawah Sepak Takraw

Keterampilan siswa dalam melakukan gerakan servis bawah sepak takraw pada siklus 1 diukur dengan menggunakan tes keterampilan servis bawah sepak takraw. Tes pada siklus 1 ini diikuti oleh 35 orang siswa. Perolehan nilai tes dengan cara mengamati tiap gerakan servis bawah hingga jatuhnya bola pada kotak point yang ada. Hasil tes keterampilan servis bawah sepak takraw pada siswa kelas X MA Al-Kariim Kabupaten Bengkulu Tengah pada siklus 1 ditunjukkan pada tabel berikut :

Tabel 4 Hasil Keterampilan Servis Bawah Sepak Takraw

\begin{tabular}{|c|c|}
\hline $\begin{array}{c}\text { Rata-Rata } \\
\text { Jumlah Siswa } \\
\text { Tuntas }\end{array}$ \\
\hline Persentase \\
Ketuntasan \\
\hline Kriteria & $60 \%$ \\
\hline \multicolumn{2}{|c|}{ Berdasarkan tabel 4.4 hasil } \\
\hline \multicolumn{2}{|c|}{ Belumtas } \\
\hline
\end{tabular}

keterampilan servis bawah sepak takraw menunjukkan bahwa dari 35 siswa yang mengikuti tes, hanya 21 (60\%) siswa yang nilainya sudah tergolong tuntas dan nilai rata-rata tes siklus 1 adalah 61,4.

Hasil Refleksi Pada Siklus 1

Kegiatan pembelajaran yang telah dilakukan pada siklus 1 menunjukkan bahwa pembelajaran PJOK pada siswa setelah diberi tindakan berupa penerapan modifikasi bola karet belum dikatakan berhasil. Belum berhasilnya pembelajaran tersebut 
dikarenakan masih banyak hal yang perlu diperbaiki baik dari segi aktivitas guru, siswa maupun hasil belajar siswa.

A. Refleksi Aktivitas Guru

Hasil analisis pengamatan aktivitas guru pada siklus 1 sebagian besar telah mendapat nilai "ya" dan terdapat 5 aspek yang belum berhasil yaitu:

(1) Guru menjelaskan tujuan pembelajaran.

(2) Guru mempraktekkan sikap awal dengan berdiri di posisi servis dengan kaki kanan di posisi belakang dan kaki kiri sebagai tumpuan.

(3) Guru memberi arahan posisi tangan seolah-olah meminta bola agar menendangnya tepat sasaran.

(4) Menunjukkan arah pandangan mata ketika bola datang.

(5) Guru menarik motivasi dan mengawasi gerak teknik sepakan yang dilakukan.

B. Refleksi Aktivitas Siswa

Hasil analisis pengamatan aktivitas siswa siklus 1 sebagian besar telah mendapat nilai "ya" dan terdapat 6 aspek yang belum berhasil yaitu:

(1) Siswa memperhatikan tujuan pembelajaran.

(2) Siswa memperhatikan materi servis bawah sepak takraw dengan tahapan-tahapan yang benar.

(3) Siswa memperhatikan sikap awal dengan berdiri di posisi servis dengan kaki kanan diposisi belakang dan kaki kiri sebagai tumpuan yang diperagakan oleh guru.

(4) Siswa memperhatikan arahan posisi tangan seolah-olah meminta bola agar menendangnya tepat sasaran yang dicontohkan oleh guru.

(5) Menunjukkan arah pandangan mata ketika bola datang.

(6) Siswa memperhatikan motivasi dan gerak teknik sepakan yang dilakukan.

C. Refleksi Keterampilan Servis Bawah Sepak Takraw

Hasil tes akhir keterampilan melakukan servis bawah sepak takraw pada siklus 1 diperoleh ratarata nilai tes siswa sebesar 61,4 dan persentase ketuntasan belajar sebesar 60\%. Dari hasil tes keterampilan servis bawah sepak takraw tersebut dinyatakan belum berhasil. Langkah perbaikan yang dapat dilakukan adalah guru lebih mengoptimalkan kemampuannya dalam mengelola pembelajaran, sehingga hasil kemampuan siswa dalam melakukan teknik servis bawah sepak takraw dapat berhasil atau tuntas.

Siklus Kedua

\section{A. Aktivitas Guru}

Hasil pengamatan aktivitas guru dalam pembelajaran yang dilakukan oleh satu orang pengamat selama kegiatan pembelajaran dengan menggunakan modifikasi bola karet sepak takraw dapat di lihat pada tabel berikut : 
Tabel 4.5 Data Hasil Aktivitas Guru pada Siklus 2

\begin{tabular}{|c|c|}
\hline ASPEK & HASIL \\
\hline Jumlah Skor & 15 \\
\hline Persentase & $\mathbf{9 3 , 7 \%}$ \\
\hline Kriteria & Tuntas \\
\hline
\end{tabular}

Berdasarkan tabel 4.5 data hasil aktivitas guru pada siklus 2 menunjukkan bahwa jumlah skor hasil pengamatan adalah 15 (93,7\%), dengan demikian kriteria yang dicapai untuk aktivitas guru pada siklus 2 adalah tuntas. Hal ini dapat disimpulkan bahwa aktivitas guru dalam pembelajaran PJOK dengan materi sepak takraw melalui penerapan modifikasi bola karet pada siklus 2 telah berhasil.

\section{B. Aktivitas Siswa}

Hasil pengamatan aktivitas siswa dalam pembelajaran yang dilakukan oleh satu orang pengamat selama kegiatan pembelajaran dengan menggunakan modifikasi bola karet sepak takraw dapat dilihat pada tabel berikut :

Tabel 6 Data Hasil Aktivitas Siswa Pada Siklus 2

\begin{tabular}{|c|c|}
\hline ASPEK & HASIL \\
\hline Jumlah Skor & 14 \\
\hline Persentase & $87,5 \%$ \\
\hline Kriteria & Tuntas \\
\hline
\end{tabular}

Berdasarkan tabel 4.6 data hasil aktivitas siswa pada siklus 2 menunjukkan bahwa jumlah skor hasil pengamatan adalah 14 (87,5\%), dengan demikian kriteria yang dicapai untuk aktivitas siswa pada siklus 2 adalah tuntas. Hal ini dapat disimpulkan bahwa aktivitas siswa dalam pembelajaran PJOK dengan materi sepak takraw melalui penerapan modifikasi bola karet pada siklus telah berhasil.

C. Deskripsi Keterampilan Servis

Bawah Sepak Takraw

Keterampilan siswa dalam melakukan gerakan servis bawah sepak takraw pada siklus 2 diukur dengan menggunakan tes keterampilan servis bawah sepak takraw. Tes pada siklus 2 ini diikuti oleh 35 orang siswa. Perolehan nilai tes dengan cara mengamati tiap gerakan servis bawah hingga jatuhnya bola pada kotak point yang ada.

Nilai hasil tes dianalisis dengan cara mencari nilai rata-rata kelas, jumlah siswa yang tuntas, persentase ketuntasan, dan kriteria keberhasilan. Hasil tes keterampilan servis bawah sepak takraw pada siswa kelas $X$ MA Al-Kariim Kabupaten Bengkulu Tengah pada siklus 2 ditunjukkan pada tabel berikut :

Tabel 7 Hasil Keterampilan Servis Bawah Sepak Takraw

\begin{tabular}{|c|c|}
\hline Rata-Rata & $\mathbf{7 8}$ \\
\hline Jumlah Siswa & 30 \\
Tuntas & \\
\hline Persentase & $85,7 \%$ \\
Ketuntasan & \\
\hline Kriteria & Tuntas \\
\hline
\end{tabular}


Berdasarkan tabel 4.7 hasil keterampilan servis bawah sepak takraw menunjukkan bahwa dari 35 siswa yang mengikuti tes, $30(85,7 \%)$ siswa yang nilainya sudah tergolong tuntas, nilai rata-rata tes siklus 2 adalah 78. Berdasarkan hasil tersebut dapat disimpulkan bahwa pembelajaran PJOK pada siklus 2 telah berhasil.

Hasil Refleksi Pada Siklus 2

Kegiatan pembelajaran yang telah dilakukan pada siklus 2 menunjukkan bahwa pembelajaran PJOK pada siswa setelah diberi tindakan berupa penerapan modifikasi bola karet dapat dikatakan berhasil. Keberhasilan tersebut dapat dilihat juga dari segi aktivitas guru, siswa maupun hasil belajar siswa.

A. Refleksi Aktivitas Guru Hasil analisis pengamatan aktivitas guru siklus 2 sebagian besar telah mendapat nilai "ya" dan hanya 1 aspek yang belum berhasil yaitu: "Menunjukkan arah pandangan mata ketika bola datang". Dengan demikian pengamatan aktivitas guru telah berhasil dengan 15 aspek yang telah di capai dan mencapai persentase $93,7 \%$.

B. Refleksi Aktivitas Siswa

Hasil analisis pengamatan aktivitas siswa siklus 2 sebagian besar telah mendapat nilai "ya" dan terdapat 2 aspek yang belum berhasil yaitu:

(1) Menunjukkan arah pandangan mata ketika bola datang.

(2) Siswa memperhatikan motivasi dan gerak teknik sepakan yang dilakukan.
Dengan demikian pengamatan aktivitas siswa telah berhasil dengan 14 aspek yang telah di capai dan pencapai persentase $87,5 \%$.

C. Refleksi Keterampilan Servis Bawah Sepak Takraw

Hasil tes akhir keterampilan melakukan servis bawah sepak takraw pada siklus 2 diperoleh ratarata nilai tes siswa sebesar 78 dan persentase ketuntasan belajar sebesar 85,7. Dari hasil tes keterampilan servis bawah sepak takraw tersebut dapat dinyatakan berhasil.

\section{Pembahasan}

Berdasarkan hasil penelitian yang telah dilakukan, dapat disimpulkan bahwa penerapan modifikasi bola karet pada pembelajaran PJOK, dapat meningkatkan keterampilan siswa dalam melakukan teknik servis bawah sepak takraw dan dapat meningkatkan aktivitas guru dan siswa dalam proses pembelajaran. Hal ini dapat dilihat pada peningkatan hasil tes melakukan servis bawah sepak takraw pra siklus, siklus 1 dan 2 diketahui bahwa pada pra siklus menunjukkan rata-rata nilai yang diperoleh 45,4 dengan persentase sebesar $28,5 \%$. 
Selanjutnya pada siklus 1 menunjukkan rata-rata nilai yang diperoleh sebesar 61,4 dengan persentase ketuntasan sebesar $60 \%$. Kemudian meningkat pada siklus 2 dengan nilai rata-rata yang di peroleh sebesar 78 dengan persentase $85,7 \%$.

Selanjutnya, dapat juga dilihat peningkatan yang terjadi pada aktivitas guru dan siswa, yaitu pada siklus 1 aktivitas guru memperoleh nilai sebesar $68,7 \%$ dengan kriteria belum tuntas dan aktivitas siswa menunjukkan nilai sebesar $62,5 \%$ dengan kriteria belum tuntas. Kemudian pada siklus 2 aktivitas guru meningkat dengan memperoleh nilai sebesar 93,7\% dengan kriteria tuntas dan aktivitas siswa memperoleh nilai sebesar $87,5 \%$ dengan kriteria tuntas.

Berdasarkan peningkatan tersebut dapat disimpulkan bahwa penggunaan penerapan modifikasi bola karet dapat meningkatkan hasil belajar siswa, yang dalam penelitian ini adalah nilai tes siswa pada saat melakukan keterampilan servis bawah sepak takraw.

\section{PENUTUP}

\section{Simpulan}

Berdasarkan hasil penelitian tindakan kelas yang telah dilaksanakan dalam 2 siklus, maka dapat ditarik kesimpulan sebagai berikut :
1. Penerapan modifikasi bola karet dalam pembelajaran PJOK dapat meningkatkan keterampilan siswa dalam melakukan servis bawah sepak takraw. Hal ini dapat dilihat dari peningkatan nilai rata-rata mulai dari pra siklus nilai rata-rata $45,4(28,5 \%)$, siklus 1 nilai ratarata $61,4(60 \%)$, dan siklus 2 nilai rata-rata $78(85,7 \%)$.

2. Penerapan modifikasi bola karet dalam pembelajaran PJOK dapat meningkatkan aktivitas guru dan siswa. Hal ini dapat dilihat dari hasil pengamatan guru dan siswa pada siklus 1 aktivitas guru memperoleh nilai $68,7 \%$ (belum tuntas) dan nilai aktivitas siswa $62,5 \%$ (belum tuntas) sedangkan pada siklus 2 mengalami peningkatan aktivitas guru memperoleh nilai 93,7\% (tuntas) dan nilai aktivitas siswa $87,5 \%$ (tuntas)

\section{Saran}

1. Bagi Sekolah

Pelajaran PJOK merupakan salah satu pembelajaran yang memerlukan banyak sarana dan prasarana yang lebih banyak dibandingkan dengan mata pelajaran yang lain, maka disarankan kepada pihak sekolah untuk lebih memperhatikan sarana dan prasarana pembelajaran Penjaskes.

2. Bagi Guru

a) Dalam proses pembelajaran sebaiknya harus mengemas pembelajaran yang mudah dimengerti, dipahami dan 
dipraktikkan oleh siswa agar peningkatan hasil belajar siswa dapat dimaksimalkan.

b) Perlu dilakukan penelitian dengan menggunakan metode pembelajaran, modifikasi media dan pengemasan pembelajaran yang lebih beragam dalam setiap materi ajar agar pembelajaran dapat berjalan dengan baik.

\section{DAFTAR PUSTAKA}

Direktorat Jendral Pendidikan Dasar Dan Menengah. MENPORA. (2000). Buku IV Materi Pelatihan Guru Pendidikan Jasmani Dan Kesehatan SD/ Pelatih Klub Olahraga Usia Dini SD. Jakarta : Dirjen Pendidikan.

Giri Wiarto. (2015). Inovasi Pembelajaran Dalam Pendidikan Jasmani. Yogyakarta : Laksitas.

Rusli Lutan. (2002). Mengajar Pendidikan Jasmani Pendekatan Pendidikan Gerak Di Sekolah Dasar. Jakarta : Direktorat Jendral Olahraga, Depdiknas.

Sadiman, A.S. dkk. (2014). Media Pendidikan. Jakarta : Raja Grafindo Persada.

Suharsimi Arikunto. (2010). Penelitian Tindakan Kelas. Yogyakarta : Aditya Media.

Sukmadinata, N.S. (2010). Metode Penelitian Pendidikan. Bandung : Remaja Rosdakarya.
Tangkudung, James. (2012). Kepelatihan Olahraga Pembinaan Prestasi Olahraga. Jakarta: Cerdas jaya ,(2016).Macam-macam Metodologi Penelitian. Jakarta: Lensa Media Pustaka Indonesia ,(2018).

Sport Psychometrics Dasar-dasar dan instrument Psikometri. Depok :Rajagrafindo persada 